\title{
Assessment of the Correlation of Commonly used Laboratory Tests with Clinical Activity, Renal Involvement and Treatment of Systemic Small-vessel Vasculitis with the Presence of ANCA Antibodies.
}

\section{Magdalena Mosakowska ( $\sim$ mmosakowska@wim.mil.pl)}

Department of Internal Diseases, Nephrology and Dialysis, Military Institute of Medicine, 128 Szaserów Street, 04-141, Warsaw

Dorota Brodowska-Kania

Department of Internal Diseases, Nephrology and Dialysis, Military Institute of Medicine, 128 Szaserów Street, 04-141, Warsaw

Katarzyna Szamotulska

Department of Epidemiology and Biostatistics, Institute of Mother and Child, 17a, Kasprzaka Street, 01-211, Warsaw

Aleksandra Rymarz

Department of Internal Diseases, Nephrology and Dialysis, Military Institute of Medicine, 128 Szaserów Street, 04-141, Warsaw

Stanisław Niemczyk

Department of Internal Diseases, Nephrology and Dialysis, Military Institute of Medicine, 128 Szaserów Street, 04-141, Warsaw

\section{Research Article}

Keywords: ANCA, vasculitis, microhematuria, CRP, ESR, procalcitonin, fibrinogen, d-dimer, complement system

Posted Date: March 22nd, 2021

DOI: https://doi.org/10.21203/rs.3.rs-308105/v1

License: (1) This work is licensed under a Creative Commons Attribution 4.0 International License. Read Full License 


\section{Abstract}

The aim of the study was to assess the correlation of commonly used laboratory tests with clinical activity, degree of kidney involvement and treatment of systemic small-vessel vasculitis with the presence of ANCA antibodies.

Methods.

The study included 28 patients with active AAV (BVAS $\geq 3$ ). The following tests were performed: MPO-ANCA, PR3-ANCA, peripheral blood count, ESR, CRP, procalcitonin, creatinine, GFR, urea, albumin, fibrinogen, d-dimer, components of the C3 and C4 complement systems, urinalysis with sediment evaluation and diurnal proteinuria. The assessments were conducted twice: at study entry (A0) and after 6 months (A6) $($ BVAS $=0)$.

Results

At the time of inclusion in the study, the mean creatinine concentration was $3.39 \mathrm{mg} / \mathrm{dl}\left(\mathrm{GFR} 33.17 \mathrm{ml} / \mathrm{min} / 1.73 \mathrm{~m}^{2}\right)$, after achieving remission in 11 patients (39.3\%) GFR remained below $30 \mathrm{ml} / \mathrm{min} / 1.73 \mathrm{~m}^{2}, 4$ patients $(14.3 \%)$ continued renal replacement therapy, and 3 patients $(10.7 \%)$ with advanced renal failure died. Microhematuria occurred in $80.9 \%$ of the studied population, withdrew in most patients, strongly correlated with renal involvement $p<0.001$ and was not related to disease severity $p=0.147$. CRP, ESR, fibrinogen, d-dimer, albumin and hemoglobin in the peripheral blood showed a strong correlation with the clinical activity of AAV and well identified severe patients. High procalcitonin concentrations correlated with a severe form of the disease, pulmonary involvement with respiratory failure and alveolar hemorrhage (mean $3.41 \mathrm{ng} / \mathrm{ml}$, median $0.91 \mathrm{ng} / \mathrm{ml}, \mathrm{SD} 7.62, \mathrm{p}=0.000$ ), and were associated with the occurrence of infectious complications and the need to administer antibiotic therapy. ANCA antibodies were useful in the evaluation of patients with AAV, the amount of antibodies did not correlate with the severity of vasculitis $(p=0.685)$ and the results in many patients did not match the expected assumptions.

Conclusions

CRP, ESR, fibrinogen, d-dimers, albumin and hemoglobin in the peripheral blood correlate well with the activity of vasculitis and identify severe patients. The resolution of microhematuria suggests remission of the disease in the renal area. Procalcitonin may be slightly increased in patients with active AAV without infection, high concentrations are strongly associated with infectious complications. ANCA antibodies should always be interpreted in the context of the observed clinical symptoms.

\section{Introduction}

ANCA associated vasculitis (AAV) is associated with necrotic inflammation in the wall of small arteries, veins and capillaries [1]. The consequence is ischemia, followed by impairment of the organ functions. The classification of AAV includes granulomatosis with polyangiitis (GPA), microscopic polyangiitis (MPA), eosinophilic granulomatosis with polyangiitis (EGPA) and renal limited-AAV (RLV).

AAV is a rare disease, the annual incidence is estimated at 5.0-10.65/million. The five-year survival rate for GPA is $74-91 \%$ and for MPA 45$76 \%[2,3]$. ANCA antibodies are detected in the serum in approximately $90 \%$ of patients, and in $10 \%$ they are absent despite the typical clinical course. The sensitivity of the detected PR3-ANCA and MPO-ANCA amounts to $85.5 \%$, and the specificity is as high as $98.6 \%$ [2,3]. Controversies concern the usefulness of testing for antibodies in monitoring vasculitis activity [4]. Patient evaluation is based on a multivariate analysis and requires extensive clinical experience. In everyday clinical practice, we observe an incomplete correlation of test results with the condition of a patient and the intensity of involvement of various organs. This applies, in particular, to the markers of inflammation, i.e. peripheral blood leukocytosis, ESR, CRP, or the amount of ANCA antibodies. Additionally, the clinical picture includes symptoms resulting from permanent organ damage that occurred during the disease, adverse events of drugs and infectious complications. The absence of markers unequivocally correlating with AAV activity and differentiating between other clinical conditions makes diagnostic and treatment difficult. The objective of the study was to assess the correlation of commonly used laboratory tests with clinical activity, degree of renal involvement and treatment of systemic small-vessel vasculitis with the presence of ANCA antibodies.

\section{Material And Methods}

The study included 28 patients with active AAV. In 16 patients the disease was newly diagnosed, and in 12 patients another exacerbation was observed. The control group included 27 patients without diagnosed autoimmune disease, matched in terms of age, sex and stage of chronic kidney disease to patients from the study group. 
The criteria for inclusion in the study were: informed consent of the patient, age over 18 years, diagnosed small-vessel vasculitis with the presence of ANCA antibodies, meeting the ACR 1990 criteria and in accordance with the CHCC 2012 nomenclature. The exclusion criteria were the lack of consent to participate in the study, inflammation of small vessels without the presence of ANCA antibodies at the diagnosis of the disease, or lack of cooperation with the patient. We obtained written informed consent from all participants. All methods were performed in accordance with the relevant guidelines and regulations.

The study protocol was approved by the Bioethics Committee of the Military Institute of Medicine in Warsaw on June 18, 2014 (No. 26/WIM/2014). The study was funded by a Grant for a Young Researcher of the Military Institute of Medicine.

A detailed analysis of clinical data was performed, disease activity and remission were verified using the BVAS/WG and BVAS v3 scales. The following laboratory tests were performed: MPO-ANCA (positive result > $5.0 \mathrm{lU} / \mathrm{ml}$ ), PR3-ANCA (positive result> $3.0 \mathrm{IU} / \mathrm{ml}$ ), peripheral blood count, ESR, CRP, procalcitonin (PCT), creatinine, GFR, urea, albumin, fibrinogen, d-dimer, components of the C3 and C4 complement systems, urinalysis with sediment evaluation and diurnal proteinuria. Patients from the study group were assessed twice: at study entry (A0) and after 6 months (A6) in the early remission stage (BVAS =0). In the control group, the most likely cause of kidney disease was identified in order to exclude concomitant glomerulonephritis and systemic diseases.

During the study, 2 patients from the study group died in the course of septic shock in the early stages of the disease, shortly after the introduction of immunosuppression, 1 person died 6 weeks after the inclusion due to severe Clostridium difficile infection and 2 individuals were disqualified as a result of non-cooperation. The remaining 23 patients were included in the comparative analysis at baseline and after 6 months of treatment.

Basic descriptive statistics such as arithmetic mean, median, standard deviation, minimum and maximum values were employed. The hypotheses regarding comparisons between the two groups were verified using the non-parametric Mann-Whitney test and the Wilcoxon test for small study groups, respectively. The verification of hypotheses concerning comparisons between more than two groups was performed using the non-parametric Kruskal-Wallis test. Trend analyzes were done with the use of the Jonckheere-Terpstra test. In the case of categorized variables, the Fisher test was employed. The significance level was set at 0.05 .

\section{Results}

In the study population with active AAV, $67.9 \%$ were women. The average age was 58.3 years. GPA was diagnosed in 16 patients (57\%) and MPA in 12 patients (43\%). The clinical activity of the disease was evaluated according to the BVAS/WG scale at 8.46 pts (min. 3 pts, max. 16 pts) and according to the BVAS v3 scale at 19.14 pts (min. 7 pts, max. 31 pts). The localized form was diagnosed in 1 person, the early systemic form in 5 people and the dominant form was generalized and severe vasculitis (22 patients; 78.6\%) [Table 1]. The lungs were involved in 24 individuals (86\%), and the upper respiratory tract in 15 (54\%). HRCT was dominated by ground-glass opacities and parenchymal infiltrates. Hemoptysis occurred in 9 patients while respiratory failure requiring mechanical ventilation or assisted respiration developed in 6 individuals.

Table 1

Characteristics of the studied population. 


\begin{tabular}{|c|c|c|}
\hline & $\begin{array}{l}\text { AAV group (A) } \\
(\mathrm{N}=28)\end{array}$ & $\begin{array}{l}\text { Control group (C) } \\
(\mathrm{N}=27)\end{array}$ \\
\hline Age, mean $\pm S D$, years & $58.32 \pm 15.14$ & $60.3 \pm 17.14$ \\
\hline \multirow[t]{2}{*}{ Sex, females/males (\%) } & $19(67.9 \%) /$ & $18(66.6 \%) /$ \\
\hline & $9(32.1 \%)$ & $9(33.3 \%)$ \\
\hline ANCA PR3/MPO & $\begin{array}{l}17(71 \%) / \\
11(29 \%)\end{array}$ & - \\
\hline BVAS v3, mean \pm SD & $19.14 \pm 7.14$ & - \\
\hline BVAS/WG, mean \pm SD & $8.46 \pm 3.66$ & - \\
\hline \multicolumn{3}{|l|}{ Organ activity } \\
\hline skin & $7(25 \%)$ & - \\
\hline joints & $24(86 \%)$ & \\
\hline upper respiratory tract & $15(54 \%)$ & \\
\hline lung & $24(86 \%)$ & \\
\hline kidneys/HD & $21(75 \%) / 12(43 \%)$ & \\
\hline nervous system & $7(25 \%)$ & \\
\hline \multirow{4}{*}{$\begin{array}{l}\text { Clinical form } \\
\text { localized and early systemic } \\
\text { generalized } \\
\text { severe }\end{array}$} & & - \\
\hline & $6(21.4 \%)$ & \\
\hline & $10(35.7 \%)$ & \\
\hline & $12(42.8 \%)$ & \\
\hline \multirow{6}{*}{$\begin{array}{l}\text { Remission induction } \\
\text { glucocorticoids } \\
\text { plasmapheresis } \\
\text { cyclophosphamide } \\
\text { rituximab } \\
\text { other }\end{array}$} & & - \\
\hline & $28(100 \%)$ & \\
\hline & $7(25 \%)$ & \\
\hline & $18(64 \%)$ & \\
\hline & $6(21 \%)$ & \\
\hline & $4(14 \%)$ & \\
\hline
\end{tabular}

In 21 patients (75\%), the kidneys were involved The creatinine concentration increased by more than $30 \%$ and/or the presence of microhematuria ( $\geq 10$ erythrocytes in the field of view) was confirmed. 9 patients $(32 \%)$ started renal replacement therapy, and 3 persons with subsequent AAV exacerbation (11\%) were treated with hemodialysis as a result of earlier disease activity. After 6 months, only 3 patients were able to complete renal replacement therapy, and the remaining 6 patients continued dialysis treatment. Within 6 months of follow-up, 3 patients $(10.71 \%)$ died due to infectious complications, in each case severe AAV was diagnosed. In the remission-inducing treatment, all patients received GCS, in 24 patients (85.71\%), oral prednisone administration was preceded by repeated infusions of methylprednisolone at $0.25-1.0 \mathrm{~g} /$ day for 3-5 days. 18 patients (64\%) received cyclophosphamide according to the protocol from the CYCLOPS study, rituximab at a dose of $375 \mathrm{mg} / \mathrm{m}^{2}$ of body surface area in four weekly infusions was administered in 6 individuals ( $21 \%$ ), mycophenolate mofetil in 2 patients (7\%) and azathioprine (increase in chronic doses during the exacerbation of the disease) in one person (4\%). 7 patients $(25 \%)$ underwent therapeutic plasma exchange. After 6 months of immunosuppressive treatment, remission was confirmed (BVAS v3 $=0 \mathrm{pts}, \mathrm{BVAS} / \mathrm{WG}=0 \mathrm{pts}$ ). Organ complications resulting from the underlying disease and/or immunosuppressive treatment were evaluated according to the VDI scale (mean $=3.5 \mathrm{pts}$, $\min -0 \mathrm{pts}$, max $-9 \mathrm{pts}$ ). 
In the studied population, the mean initial concentration of creatinine was high and amounted to $3.39 \mathrm{mg} / \mathrm{dl}$ (mean GFR $33.17 \mathrm{ml} / \mathrm{min} / 1.73$ $\mathrm{m}^{2}$ ) and after 6 months of treatment it decreased only to $2.86 \mathrm{mg} / \mathrm{dl}$ (mean GFR $37.87 \mathrm{ml} / \mathrm{min} / 1.73 \mathrm{~m}^{2}$ ). The difference was not statistically significant [Table 2].

Table 2

Laboratory test results - assessment of kidney involvement.

\begin{tabular}{|c|c|c|c|c|c|}
\hline & Initially active AAV (A0) & $P *$ & $\begin{array}{l}\text { AAV remission } \\
\text { (A6) }\end{array}$ & Control group & $P * *$ \\
\hline $\begin{array}{l}\text { Creatinine, } \\
\text { mean, mg/dl }\end{array}$ & $3.39 \pm 2.21$ & 0.051 & $2.86 \pm 2.05$ & $4.05 \pm 3.51$ & 0.427 \\
\hline $\begin{array}{l}\text { eGFR, } \\
\text { mean, } \mathrm{ml} / \mathrm{min} / 1.73 \mathrm{~m}^{2}\end{array}$ & $33.17 \pm 30.46$ & 0.054 & $37.87 \pm 31.11$ & $33.6 \pm 33.3$ & 0.436 \\
\hline $\begin{array}{l}\text { Urea, } \\
\text { mean, mg/dl }\end{array}$ & $97,69 \pm 62,04$ & 0,123 & $88,13 \pm 49,49$ & $94,04 \pm 51,7$ & 0,298 \\
\hline $\begin{array}{l}\text { Proteinuria, } \\
\text { mean, g/24 h }\end{array}$ & $1.07 \pm 1.5$ & 0.275 & $0.75 \pm 0.93$ & $0.88 \pm 1.66$ & 0.425 \\
\hline $\begin{array}{l}\text { Microhematuria } \\
>4\end{array}$ & $81.9 \%$ & $<0.001$ & $18 \%$ & $19 \%$ & $<0.001$ \\
\hline
\end{tabular}

Only in 4 patients (14.3\%) the GFR value increased above $60 \mathrm{ml} / \mathrm{min} / 1.73 \mathrm{~m}^{2}$, in $11(39.3 \%)$ it remained below $30 \mathrm{ml} / \mathrm{min} / 1.73 \mathrm{~m}$, including 3 patients $(10.7 \%)$ had to continue renal replacement therapy, 3 people $(10.7 \%)$ with advanced renal failure died. The amount of daily proteinuria did not show a significant correlation with AAV activity $(p=0.275)$, and the percentage of patients in remission with daily protein excretion above $150 \mathrm{mg}$ was as high as $62.5 \%$ [Table 2, 3].

Table 3

Parameters related to AAV activity within the kidneys depending on the severity of the disease.

\begin{tabular}{|lllllll|}
\hline Disease form & & Creatinine & GFR & Urea & Proteinuria & Microhematuria \\
\hline localized and early systemic $n=6$ & mean & 2,28 & 69,50 & 53,33 & 0,28 & 1,0 \\
\cline { 2 - 7 } & SD & 3,44 & 34,80 & 40,15 & 0,32 & 1,55 \\
\cline { 2 - 7 } & median & 0,900 & 90,00 & 40,00 & 0,15 & 0,00 \\
\hline generalized $n=10$ & mean & 2,55 & 35,00 & 75,70 & 1,15 & 2,56 \\
\cline { 2 - 7 } & SD & 1,29 & 24,71 & 34,78 & 0,98 & 1,01 \\
\hline \multirow{2}{*}{ severe $n=12$} & median & 2,40 & 26,50 & 77,00 & 0,88 & 3,00 \\
& mean & 5,32 & 10,25 & 151,08 & 1,28 & 2,55 \\
\hline P in the Kruskal-Wallis test & SD & 1,44 & 3,69 & 58,73 & 1,78 & 0,69 \\
\hline P in the Jonckheere-Terpstra test for the trend & $\mathbf{0 , 0 0 0}$ & $\mathbf{0 , 0 0 0}$ & $\mathbf{0 , 0 0 0}$ & 0,064 & 0,147 \\
\hline
\end{tabular}

The occurrence of microhematuria was strongly related to AAV activity in the kidneys. In $57.1 \%$ of patients, microhematuria covering the field of view was observed, in another $23.8 \%$ exceeded the value recognized as normal. After achieving remission, it withdrew in almost all patients, and the difference was statistically significant $(p<0.001)$ [Figure 1]. 
At the time of AAV diagnosis, peripheral blood leukocytosis was significantly elevated compared to the control group ( $p<0.001$ ), the degree of leukocytosis increase did not correlate with the severity of the disease, and it did not decrease significantly in the follow-up, most likely due to the effect of GCS treatment $(p=0.249)$ [table 4, 5]. Inflammation parameters of CRP and ESR showed a strong association with, both, activity and severity of AAV $(p<0.001)$. In the majority of patients, foci of infection were excluded, and peripheral blood and urine cultures were sterile. In the most severe patients, the exclusion of infection was very difficult, and it was necessary to administer broadspectrum antibiotics. In order to differentiate high CRP values, procalcitonin was determined. The mean PCT concentration in patients with active AAV was $0.6 \mathrm{ng} / \mathrm{ml}$, median $0.17 \mathrm{ng} / \mathrm{ml}$ and was significantly higher compared to the remission period of the disease (mean 0.19 $\mathrm{ng} / \mathrm{ml}$, median $0.08 \mathrm{ng} / \mathrm{ml}, \mathrm{p}<0.001$ ). In 5 patients (22\%), PCT concentrations were: $0.98 \mathrm{ng} / \mathrm{ml}, 0.85 \mathrm{ng} / \mathrm{ml}, 0.7 \mathrm{ng} / \mathrm{ml}, 1.01 \mathrm{ng} / \mathrm{ml}, 0.62$ $\mathrm{ng} / \mathrm{ml}$ respectively and were in the so-called a gray zone of 0.5 to $2.0 \mathrm{ng} / \mathrm{ml}$ despite no active infection. 2 female patients ( $9 \%$ ) with PCT of $4.17 \mathrm{ng} / \mathrm{ml}$ and $3.52 \mathrm{ng} / \mathrm{ml}$ had a severe form of vasculitis with pulmonary involvement, respiratory failure and alveolar hemorrhage, requiring broad-spectrum antibiotic therapy. 2 women who died in the course of septic shock (PCT: $27.28 \mathrm{ng} / \mathrm{ml}, 1.22 \mathrm{ng} / \mathrm{ml})$ were excluded from the comparative analysis. Procalcitonin concentration levels were particularly high in patients with severe AAV [Table 4, 5]. The concentration of fibrinogen in active AAV was significantly increased in 16 patients (69.5\%) and showed a strong relationship with the severity of the disease $(p=0.011)$. The concentration of platelets in the peripheral blood, although in most patients within the reference values, was statistically significantly higher in active AAV than in remission (289 thous./ul vs 234 thous./ul; $p=0.024$ ). However, it did not differ significantly from the results in the control group $(p=0.213)$ and was not related to the severity of the disease [Table 4,5$]$.

Table 4

Laboratory test results. 


\begin{tabular}{|c|c|c|c|c|c|}
\hline & Initially active AAV (A0) & $P *$ & $\begin{array}{l}\text { AAV remission } \\
\text { (A6) }\end{array}$ & Control group & $\mathrm{P} * *$ \\
\hline \multicolumn{6}{|c|}{ ANCA IU/ml } \\
\hline mean & 68,16 & $<0,001$ & 25,68 & 0,2 & $<0,001$ \\
\hline median & 51,0 & & 4,5 & 0,2 & \\
\hline SD & 62,10 & & 44,02 & 0,27 & \\
\hline $\min -\max$ & $2,2-197,0$ & & $0,1-177,0$ & $0,0-1,3$ & \\
\hline \multicolumn{6}{|c|}{ Leukocytosis $\times 10 \backslash \backslash^{\wedge} 9 / /$} \\
\hline mean & 10,7 & 0,262 & 9,45 & 6,82 & $<0,001$ \\
\hline median & 9,6 & & 9,27 & 6,41 & \\
\hline SD & 3,84 & & 2,80 & 1,97 & \\
\hline min-max & $3,45-19,45$ & & $5,9-16,06$ & $3,59-12,19$ & \\
\hline \multicolumn{6}{|c|}{ Hemoglobin $\mathrm{g} / \mathrm{dl}$} \\
\hline mean & 10,11 & 0,002 & 11,61 & 12,78 & $<0,001$ \\
\hline median & 10,3 & & 11,3 & 13,2 & \\
\hline SD & 2,16 & & 1,90 & 1,89 & \\
\hline $\min -\max$ & $5,5-14,8$ & & $6,25-15,3$ & $9,8-16,1$ & \\
\hline \multicolumn{6}{|c|}{ Platelets $\times 10 \backslash \backslash^{\wedge} 9 / /$} \\
\hline mean & 289,2 & 0,024 & 234,6 & 240,5 & 0,213 \\
\hline median & 269,0 & & 236,0 & 239,0 & \\
\hline SD & 121,9 & & 64,26 & 56,16 & \\
\hline $\min -\max$ & $81,0-616,0$ & & $149,0-354,0$ & $146,0-341,0$ & \\
\hline \multicolumn{6}{|c|}{ ESR $\mathrm{mm} / 1 \mathrm{~h}$} \\
\hline mean & 63,26 & $<0,001$ & 22,13 & 23,87 & $<0,001$ \\
\hline median & 56,0 & & 17,0 & 26,0 & \\
\hline SD & 41,20 & & 15,15 & 15,49 & \\
\hline $\min -\max$ & $11,0-140,0$ & & $3,0-61,0$ & $2,0-50,0$ & \\
\hline \multicolumn{6}{|c|}{ CRP mg/dl } \\
\hline mean & 5,15 & $<0,001$ & 0,3 & 0,8 & $<0,001$ \\
\hline median & 2,0 & & 0,2 & 0,3 & \\
\hline SD & 7,09 & & 0,24 & 1,75 & \\
\hline $\min -\max$ & $0,1-24,4$ & & $0,1-0,8$ & $0,1-8,4$ & \\
\hline \multicolumn{6}{|c|}{ Procalcitonin $\mathrm{ng} / \mathrm{ml}$} \\
\hline mean & 0,60 & $<0,001$ & 0,14 & 0,19 & 0,094 \\
\hline median & 0,17 & & 0,05 & 0,08 & \\
\hline SD & 1,07 & & 0,21 & 0,28 & \\
\hline $\min -\max$ & $0,02-4,17$ & & $0,0-0,91$ & $0,0-1,25$ & \\
\hline \multicolumn{6}{|c|}{ Albumin $\mathrm{g} / \mathrm{dl}$} \\
\hline mean & 3,7 & $<0,001$ & 4,31 & 4,43 & $<0,001$ \\
\hline median & 3,6 & & 4,3 & 4,4 & \\
\hline
\end{tabular}




\begin{tabular}{|c|c|c|c|c|c|}
\hline SD & 0,68 & & 0,35 & 0,39 & \\
\hline $\min -\max$ & $2,6-5,0$ & & $3,4-4,9$ & $3,7-5,2$ & \\
\hline \multicolumn{6}{|c|}{ Fibrinogen $\mathrm{mg} / \mathrm{dl}$} \\
\hline mean & 488,0 & 0,011 & 378,69 & 435,8 & 0,208 \\
\hline median & 443,0 & & 379,0 & 439,0 & \\
\hline SD & 162,67 & & 89,9 & 113,5 & \\
\hline $\min -\max$ & $224,0-776,0$ & & $239-515,0$ & $251,0-681,0$ & \\
\hline \multicolumn{6}{|l|}{ D-dimer } \\
\hline mean & 6,59 & 0,004 & 1,96 & 0,83 & $<0,001$ \\
\hline median & 2,19 & & 0,79 & 0,57 & \\
\hline SD & 12,63 & & 3,51 & 0,79 & \\
\hline $\min -\max x$ & $0,22-60,3$ & & $0,10-16,66$ & $0,11-3,40$ & \\
\hline \multicolumn{6}{|l|}{ C3 } \\
\hline mean & 115,9 & 0,414 & 111,34 & 114,65 & 0,876 \\
\hline median & 114,0 & & 106,0 & 116,0 & \\
\hline SD & 20,25 & & 17,61 & 15,65 & \\
\hline $\min -\max$ & $80,0-153,0$ & & $85,0-149,0$ & $89,0-140,0$ & \\
\hline \multicolumn{6}{|l|}{ C4 } \\
\hline mean & 23,26 & 0,011 & 26,87 & 26,39 & 0,125 \\
\hline median & 23,0 & & 27,0 & 25,0 & \\
\hline SD & 6,74 & & 5,25 & 6,28 & \\
\hline $\min -\max$ & $12,0-41,0$ & & $18,0-38,0$ & $18,0-43,0$ & \\
\hline
\end{tabular}

Table 5

Comparison of test results depending on the severity of AAV. 


\begin{tabular}{|c|c|c|c|c|c|c|c|c|c|c|c|c|c|}
\hline \multicolumn{2}{|c|}{ Disease form } & \multirow{2}{*}{$\begin{array}{l}\text { ANCA } \\
93,33\end{array}$} & \multirow{2}{*}{$\begin{array}{r}\text { WBC } \\
11,37\end{array}$} & \multirow{2}{*}{$\begin{array}{l}\mathrm{Hb} \\
11,37\end{array}$} & \multirow{2}{*}{$\begin{array}{l}\text { PLT } \\
245,33\end{array}$} & \multirow{2}{*}{$\begin{array}{l}\text { ESR } \\
24,83\end{array}$} & \multirow{2}{*}{$\begin{array}{l}\text { CRP } \\
0,75\end{array}$} & \multirow{2}{*}{$\begin{array}{l}\text { PCT } \\
0,07\end{array}$} & \multirow{2}{*}{$\begin{array}{l}\text { Albumin } \\
4,23\end{array}$} & \multirow{2}{*}{$\begin{array}{l}\begin{array}{l}\text { Fibri- } \\
\text { nogen }\end{array} \\
342,83\end{array}$} & \multirow{2}{*}{$\begin{array}{l}\text { d- } \\
\text { dimer } \\
2,08\end{array}$} & \multirow{2}{*}{$\begin{array}{l}\text { C3 } \\
114,0\end{array}$} & \multirow{2}{*}{$\begin{array}{l}\text { C4 } \\
26,33\end{array}$} \\
\hline localized & mean & & & & & & & & & & & & \\
\hline systemic & SD & 75,58 & 3,24 & 1,02 & 120,98 & 12,27 & 0,92 & 0,07 & 0,39 & 102,49 & 2,34 & 14,42 & 3,93 \\
\hline & median & 89,00 & 11,49 & 11,7 & 240,50 & 23,00 & 0,25 & 0,04 & 4,30 & 324,0 & 1,08 & 113,5 & 28,00 \\
\hline \multirow{3}{*}{$\underset{n=10}{\text { generalized }}$} & mean & 57,63 & 9,61 & 10,74 & 308,50 & 57,00 & 2,73 & 0,18 & 3,74 & 426,7 & 1,84 & 116,9 & 22,3 \\
\hline & SD & 42,86 & 3,66 & 2,50 & 113,46 & 44,86 & 3,67 & 0,21 & 0,72 & 85,65 & 2,41 & 21,81 & 5,73 \\
\hline & median & 54,00 & 8,92 & 10,95 & 262,50 & 43,50 & 1,40 & 0,07 & 3,65 & 426,5 & 0,77 & 113,5 & 22,0 \\
\hline \multirow{3}{*}{$\begin{array}{l}\underset{n=12}{\text { severe }} \\
\quad\end{array}$} & mean & 83,04 & 11,91 & 8,69 & 282,08 & 81,67 & 10,31 & 3,41 & 3,37 & 572,92 & 13,25 & 115,7 & 23,73 \\
\hline & SD & 79,69 & 4,55 & 1,53 & 126,83 & 31,39 & 9,47 & 7,62 & 0,72 & 165,28 & 16,41 & 21,74 & 8,29 \\
\hline & median & 53,00 & 10,3 & 8,65 & 285,00 & 85,00 & 6,90 & 0,91 & 3,20 & 590,5 & 8,51 & 124,0 & 22,0 \\
\hline \multicolumn{2}{|c|}{$\begin{array}{l}\mathrm{P} \text { in the Kruskal-Wallis } \\
\text { test }\end{array}$} & 0,661 & 0,285 & 0,009 & 0,577 & 0,007 & 0,006 & 0,000 & 0,043 & 0,009 & 0,001 & 0,966 & 0,292 \\
\hline \multicolumn{2}{|c|}{$\begin{array}{l}\mathrm{P} \text { in the Jonckheere- } \\
\text { Terpstra test for the } \\
\text { trend }\end{array}$} & 0,685 & 0,639 & 0,003 & 0,685 & 0,002 & 0,001 & 0,000 & 0,013 & 0,001 & 0,001 & 0,875 & 0,333 \\
\hline
\end{tabular}

The results of the study showed a strong relationship o the increased concentration of d-dimer and the activity and severity of systemic vasculitis. Prior to the initiation of remission-inducing treatment, the mean concentration of fibrin degradation products was as high as 6.59 $\mu \mathrm{g} / \mathrm{ml}$ (median $2.19 \mu \mathrm{g} / \mathrm{ml}$ ) and was significantly higher than in the control group $(\mathrm{p}<0.001)$. Additionally, the result exceeded the reference value in $91 \%$ of patients (no patient was clinically diagnosed with overt venous thrombosis). After 6 months of immunosuppressive treatment, the mean concentration of $d$-dimer decreased and returned to normal in the majority of patients $(p=0.004)$. [table 4, 5]. Patients with active vasculitis were characterized by a lower concentration of hemoglobin and albumin in the peripheral blood compared to the control group and the evaluation peformed in remission. These parameters also strongly correlated with the severity of the disease $(p=0.003, p=0.013)$. Components of the $C 3$ and $C 4$ complement systems did not change significantly in the studied groups.

At the time of diagnosis of active AAV, the ANCA concentration was significantly increased, the mean value was $68.16 \mathrm{IU} / \mathrm{ml}$, and the median was $51.0 \mathrm{IU} / \mathrm{ml}$. The administered treatment decreased ANCA in the majority of patients, but the mean value was as high as 25.68 $\mathrm{IU} / \mathrm{ml}(\mathrm{p}<0.001)$ [Table 4, 5]. Decrease of ANCA below the cut-off point for positive result was found in only 7 of 23 patients, while in 10 patients the ANCA concentration was only partially reduced. In the studied population, in one female patient, ANCA did not decrease and remained at a high level of $>177 \mathrm{IU} / \mathrm{ml}$ in complete clinical remission, in another woman the concentration of antibodies increased from 51 $\mathrm{IU} / \mathrm{ml}$ to $78 \mathrm{IU} / \mathrm{ml}$. In the remaining 4 patients, despite the low initial ANCA concentrations of 2.2-5.2 IU/ml, high clinical activity of the disease was observed, three patients were diagnosed with severe disease, and one with generalized disease. ANCA antibodies showed no correlation with the severity of GPA/MPA $(p=0.68)$ [Table 5$]$.

\section{Discussion}

The study analyzed the results of laboratory tests at different stages of AAV disease and treatment. The course of the disease is very variable, the assessment of the patient is based on experience and extensive differential diagnosis. The clinical activity scales BVAS v3 and BVAS/WG have a documented value for the assessment of the severity of the disease, but the classification of symptoms depends on the experience of the doctor [5].

The study population was characterized by high disease activity, more than $78 \%$ of patients were diagnosed with the generalized and severe form. Renal involvement was confirmed in $75 \%$ of patients, with initially high creatinine levels, which in most patients did not return to normal despite the treatment. The studies by Houben et al. and Hanaoka et al. showed that the increased concentration of creatinine and the decrease in GFR below $60 \mathrm{ml} / \mathrm{min} / 1.73 \mathrm{~m}^{2}$ at the time of diagnosis are late indicators of AAV activity in the kidneys, which is consistent with the presented work. Despite treatment, a significant proportion of patients remain in the advanced stage of chronic kidney disease, which significantly worsens the long-term prognosis [6,7].

The study showed a strong correlation between the presence of microhematuria and the activity of the disease in the kidneys. After achieving remission, erythrocyturia resolved in almost all patients. Monitoring of the urine sediment for the presence of red blood cells is of 
great importance for the assessment of inflammation within the glomeruli, and its resolution confirms remission, which has also been demonstrated in other studies [6-9]. The disappearance of proteinuria is likely to indicate remission of inflammation as well. Persistent proteinuria may be difficult to interpret, as it may result from irreversible changes in the kidneys or from the imposition of comorbidities such as hypertension or diabetes.

Patients with active vasculitis, particularly in the generalized and severe form, are characterized by a high intensity of inflammation. Secondary to inflammation, AAV patients had lower concentrations of hemoglobin and albumin in peripheral blood compared to the control group and to the evaluation performed in remission. These parameters strongly correlated with the severity of the disease $(p=0.003$, $p=0.013)$. On the other hand, peripheral blood leukocytosis had a low value in AAV monitoring, which was also observed in the reports of other researchers [10]. However, studies demonstrated a high correlation of the increased concentration of CRP and the ESR value with AAV activity, as well as with the severity of the disease. After effective treatment, CRP concentration returned to normal in all patients, and ESR decreased significantly. Similar observations were made in numerous clinical trials, although the non-specificity of these parameters and the inability to differentiate from infectious complications were emphasized $[11,12,13]$. The study by Kalsch et al. also showed that an increase in CRP and an acceleration of OB are observed only in the presence of clinical symptoms of AAV activity and are not useful in predicting an impending exacerbation [14]. These parameters are also of low value in the assessment of localized and early systemic AAV, where the results may remain within the normal range despite the disease process.

The most important cause of death in the active phase of AAV are infectious complications, and the increase in inflammatory markers (leukocytosis, ESR, CRP) is equally typical for vasculitis and severe infection [15]. Repeated measurements of procalcitonin concentrations proved to be very helpful in the differentiation of bacterial infection, and their effectiveness in diagnostics has been demonstrated in many clinical studies $[16,17]$.

In the presented study, procalcitonin concentration was significantly higher in active vasculitis than in remission. The highest values were found in patients with severe AAV, who developed respiratory failure, alveolar bleeding, the need for mechanical ventilation or NIV assisted respiration. In all these patients broad-spectrum antibiotic therapy was used. Two patients from this population eventually died from septic shock.

The correct procalcitonin concentration of $<0.5 \mathrm{ng} / \mathrm{ml}$ is likely to exclude significant bacterial infection. In patients with AAV during the period of disease activity, results are often observed in the so-called gray zone $(0.5-1.0 \mathrm{ng} / \mathrm{ml})$, despite the absence of infectious symptoms, which may be due to a generalized inflammatory reaction. In the presented study, similarly to other clinical trials, procalcitonin concentration above $1.0 \mathrm{ng} / \mathrm{ml}$ was strongly associated with infectious complications, severe lower respiratory tract involvement and an increased risk of death $[16,17]$.

Numerous studies have shown an increased risk of venous thrombosis in the course of active AAV $[18,19]$. The relationship of the markers stimulating the coagulation system and fibrinolysis with the activity of systemic vasculitis is less well documented [20]. The platelet counts in the majority of patients with active GPA/MPA (82.14\%) did not exceed the normal values, and the mean and median concentrations were low compared to the observations of other researchers [20]. In the presented work and in numerous other studies, an increased concentration of fibrinogen was observed in severe active vasculitis $[20,21]$. The concentration of d-dimer proved to be a strong indicator of inflammation activity and a good marker of remission in other clinical studies as well [21, 22]. In the present work, a particularly high concentration of d-dimer was observed in the severe form of AAV $(13.25 \mu \mathrm{g} / \mathrm{ml})$, while in the generalized, early systemic and localized form it was significantly lower and did not differ significantly within these subgroups (2.08-1.84 $\mu \mathrm{g} / \mathrm{ml})$. Despite the increased risk of /hemorrhage in this population, increased vigilance and appropriate prophylaxis of thromboembolism are necessary due to the above observations.

The complement system has long not been associated with small-vessel vasculitis connected with the presence of ANCA. A significant role of alternative activation in the pathogenesis of this disease has been demonstrated only in recent years, $[23,24,25]$. The studies by Augusto et al. and Crnogorac et al. showed a worse prognosis of patients with regard to survival and renal function in the group with decreased component values of the C3 complement system,. However, no such relationship was found for the C4 component [25]. In the presented study, the concentrations of $\mathrm{C} 3$ and $\mathrm{C} 4$ complement components did not differ significantly depending on the activity of systemic vasculitis.

ANCA antibodies testing is crucial in the diagnosis of AAV. However, in monitoring disease activity, the interpretation of the results arouses controversy $[4,26,27,28,29]$.

The presented study shows that in the population with newly diagnosed AAV and in exacerbation, the concentration of ANCA antibodies is significantly higher than in remission. This is confirmed by the strong relationship between the amount of ANCA and AAV activity. As in the 
reports of other researchers, it has been shown that a significant decrease of ANCA concentration in the serum correlates well with the achievement of clinical remission [30,31,32,33]. It was demonstrated, however, that in the majority of patients in remission, ANCA antibodies were not completely eliminated, and despite the decrease in concentration, they still remained at a significant level. The present study shows that ANCA antibodies were still detected in the serum in $52 \%$ of patients after 6 months of treatment despite the absence of disease activity (BVAS v3, BVAS/WG = 0 pts). We also observe patients whose ANCA concentration does not decrease or even increases despite effective treatment and the lack of clinical symptoms. In our study, ANCA antibodies also showed no correlation with AAV severity. This means that with high specificity for vasculitis, ANCA antibody measurements have limited sensitivity in disease monitoring, and any change in concentration should only be a guideline that requires interpretation in a clinical context [33].

In summary, the diagnosis of vasculitis is not easy, requires extensive clinical experience and access to immunological and histopathological tests. Appropriate treatment, both inductive and supportive, is even more challenging. The absence of markers unequivocally correlating with disease activity and differentiating from other clinical conditions makes management difficult. We expect that the results of the presented study will serve for a better interpretation of the available laboratory tests.

\section{Conclusions}

Routinely performed laboratory tests such as CRP, ESR, fibrinogen, d-dimer, albumin and hemoglobin in the peripheral blood show a strong correlation with the clinical activity of AAV and at the same time well identify patients with severe disease.

Procalcitonin was slightly increased in patients with active AAV without infection. Its high values correlated with severe involvement of the respiratory system and showed a strong relationship with the occurrence of infectious complications. PCT monitoring may/can improve the safety of immunosuppressive therapy.

Repeated determinations of ANCA antibodies are useful in assessing AAV, although the expected relationship between the amount of antibodies and disease activity is not found in many patients. Therefore, the results should always be interpreted in the context of the occurrence of clinical symptoms.

The presented study showed that patients with high creatinine concentrations in the course of AAV remain in the advanced stage of chronic kidney disease, which significantly worsens the long-term prognosis. Microhematuria was found to be an early and sensitive marker of disease activity, and its resolution indicated remission of glomerular inflammation.

\section{Abbreviations}

ACR: American College of Rheumatology; AAV: ANCA associated vasculitis; BVAS : Birmingham Vasculitis Activity Score; BVAS/WG: Birmingham Vasculitis Activity Score for Wegener's Granulomatosis; CHCC: Chapel Hill Consensus Conference; CRP: C-reactive protein; EGPA: eosinophilic granulomatosis with polyangiitis; ESR : erythrocyte sedimentation rate; GCS: glucocorticosteroids; GFR: glomerular filtration rate; GPA: granulomatosis with polyangiitis; HD: hemodialysis; MPA: microscopic polyangiitis; PCT: procalcitonin; RLV: renal limited-AAV; VDI; Vasculitis Damage Index.

\section{Declarations}

\section{Ethics approval and consent to participate .}

The study protocol was approved by the Bioethics Committee of the Military Institute of Medicine in Warsaw on June 18, 2014 (No. 26/WIM/2014). We obtained written informed consent from all participants.

\section{Consent for publication-}

NA/Not Applicable.

\section{Availability of data and materials.}

The datasets analyzed during the current study are available from the first author on reasonable request. 


\section{Competing interests.}

The authors have no conflicts of interest related to this article.

\section{Funding.}

The study was funded by a Grant for a Young Researcher of the Military Institute of Medicine.

\section{Authors' contributions.}

All authors conceived and designed the study, acquired and interpreted the data and drafted the manuscript; K.S. performed statistical analyzes. All authors reviewed the manuscript.

\section{Acknowledgements}

None.

\section{References}

1. Leavitt RY, Fauci AS, Bloch DA, Michel BA, Hunder GG, Arend WP et al: The American College of Rheumatology 1990 criteria for the classification of Wegener's granulomatosis. Arthritis Rheum. 1990 Aug;33(8):1101-7.

2. Yates M, Watts RA, Bajema IM, Cid MC, Crestani B, Hauser T, et al: EULAR/ERA-EDTA recommendations for the management of ANCAassociated vasculitis. Ann Rheum Dis 2016;75: 1583-1594.

3. Wiatr E, Gawryluk D: Pierwotne systemowe zapalenia na־czyń związane z przeciwciałami przeciw-cytoplazmatycznymi (ANCA) rekomendacje diagnostyczne i lecznicze: Pneumo nnol. Alergol. Pol. 2013; 81: 479-491.

4. Stegeman CA: Anti-neutrophil cytoplasmic antibody (ANCA) levels directed against proteinase-3 and myeloperoxidase are helpful in predicting disease relapse in ANCA-associated small-vessel vasculitis. Nephrol Dial Transplant (2002) 17: 2077-2080.

5. Suppiah R, Mukhtyar C, Flossmann O, Alberici F, Baslund B, Batra R et al: A cross-sectional study of the Birmingham Vasculitis Activity Score version 3 in systemic vasculitis. Rheumatology 2011;50:899-905.

6. Houben E, van der Heijden JW, van Dam B, Bax WA, Voskuyl AE, Penne EL: Screening for renal involvement in ANCA-associated vasculitis: room for improvement? Neth J Med. 2017 Jan;75(1):21-26.

7. Hanaoka H, Ota Y, Takeuchi T, Kuwana M: Poor renal outcomes in patients with anti-neutrophil cytoplasmic antibody-associated crescentic glomerulonephritis and normal renal function at diagnosis. Clin Rheumatol. 2016 Feb;35(2):495-500.

8. Geetha D, Seo P, Ellis C, Kuperman M, Levine SM: Persistent or new onset microscopic hematuria in patients with small vessel vasculitis in remission: findings on renal biopsy. J Rheumatol. 2012 Jul;39(7):1413-7.

9. Lv L, Chang DY, Li ZY, Chen M, Hu Z, Zhao MH: Persistent hematuria in patients with antineutrophil cytoplasmic antibody-associated vasculitis during clinical remission: chronic glomerular lesion or low-grade active renal vasculitis? BMC Nephrol. 2017 Dec 6;18(1):354

10. Cartin-Ceba R, Peikert T, Specks U: Pathogenesis of ANCA-Associated Vasculitis. Rheum Dis Clin North Am. 2010 August ; 36(3): 463477.

11. Monach PA, Warner RL, Tomasson G, Specks U, Stone JH, Ding L et al: Serum proteins reflecting inflammation, injury and repair as biomarkers of disease activity in ANCA-associated vasculitis. Ann Rheum Dis 2013;72:1342-1350.

12. Hind CR, Winearls CG, Lockwood CM, Rees AJ, Pepys MB: Objective monitoring of activity in Wegener's granulomatosis by measurement of serum C-reactive protein concentration. Clin Nephrol 1984;21:341-5.

13. Csernok E, Bossuyt X: Investigations in systemic vasculitis. The role of the laboratory. Best Pract Res Clin Rheumatol. 2018 Feb;32(1):52-62.

14. Kälsch Al, Csernok E, Münch D, Birck R, Yard BA, Gross W et al : Use of highly sensitive C-reactive protein for followup of Wegener's granulomatosis. J Rheumatol. 2010 Nov;37(11):2319-25.

15. Yang L, Xie H, Liu Z, Chen Y, Wang J, Zhang H et al: Risk factors for infectious complications of ANCA-associated vasculitis: a cohort study. BMC Nephrol. 2018 Jun 14;19(1):138.

Page $12 / 14$ 
16. Eberhard OK, Haubitz M, Brunkhorst FM, Kliem V, Koch KM, Brunkhorst R: Usefulness of procalcitonin for differentiation between activity of systemic autoimmune disease (systemic lupus erythematosus/systemic antineutrophil cytoplasmic antibody-associated vasculitis) and invasive bacterial infection. Arthritis Rheum. 1997 Jul;40(7):1250-6.

17. Moosig F, Csernok E, Reinhold-Keller E, Schmitt W, Gross WL: Elevated procalcitonin levels in active Wegener's granulomatosis. J Rheumatol. 1998 Aug;25(8):1531-3.

18. Springer J, Villa-Forte A: Thrombosis in vasculitis. Curr Opin Rheumatol. 2013 Jan;25(1):19-25.

19. Allenbach Y, Seror R, Pagnoux C, Teixeira L, Guilpain P, Guillevin L: French Vasculitis Study Group. High frequency of venous thromboembolic events in Churg-Strauss syndrome, Wegener's granulomatosis and microscopic polyangiitis but not polyarteritis nodosa: a systematic retrospective study on 1130 patients. Ann Rheum Dis. 2009 Apr;68(4):564-7.

20. Willeke P, Kümpers P, Schlüter B, Limani A, Becker H, Schotte H: Platelet counts as a biomarker in ANCA-associated vasculitis. Scand J Rheumatol. 2015;44(4):302-8.

21. Ma TT, Huang YM, Wang C, Zhao MH, Chen M: Coagulation and fibrinolysis index profile in patients with ANCA-associated vasculitis. PLoS One. 2014 May 19;9(5):e97843.

22. Hergesell O, Andrassy K, Nawroth P: Elevated levels of markers of endothelial cell damage and markers of activated coagulation in patients with systemic necrotizing vasculitis. Thromb Haemost. 1996 Jun;75(6):892-8.

23. Yuan J, Gou SJ, Huang J, Hao J, Chen M, Zhao MH: C5a and its receptors in human anti-neutrophil cytoplasmic antibody (ANCA)associated vasculitis. Arthritis Res Ther. 2012 Jun 12;14(3):R140.

24. Chen M, Daha MR, Kallenberg CG: The complement system in systemic autoimmune disease. J Autoimmun. 2010 May;34(3):J276-86.

25. Augusto JF, Langs V, Demiselle J, Lavigne C, Brilland B, Duveau A et al: Low Serum Complement C3 Levels at Diagnosis of Renal ANCA-Associated Vasculitis Is Associated with Poor Prognosis. PLoS One. 2016 Jul 8;11(7):e0158871.

26. Hagen EC, Daha MR, Hermans J, Andrassy K, Csernok E, Gaskin G et al: Diagnostic value of standardized assays for anti-neutrophil cytoplasmic antibodies in idiopathic systemic vasculitis. ECuBCR Project for ANCA Assay Standardization. Kidney Int 1998; 53: 743753.

27. Girard T, Mahr A, Noel L-H, Cordier J-F, Lesavvre P, Andre M-H, Guillevin L: Are antineutrophil cytoplasmic antibodies a marker of relapse in Wegener's granulomatosis? A prospective study. Rheumatology (Oxford) 2001; 40: 147-151.

28. Boomsma MM, Stegeman CA, van der Leij MJ, Oost W, Hermans J, Kallenberg CG et al: Prediction of relapses in Wegener's granulomatosis by measurement of antineutrophil cytoplasmic antibody levels: a prospective study. Arthritis Rheum 2000;43:2025-33

29. Finkielman JD, Merkel PA, Schroeder D, Hoffman GS, Spiera R, St Clair EW et al; WGET Research Group: Antiproteinase 3 antineutrophil cytoplasmic antibodies and disease activity in Wegener granulomatosis. Ann Intern Med 2007;147:611-19.

30. Specks U, Wheatley CL, McDonald TJ, Rohrbach MS, DeRemee RA: Anticytoplasmic autoantibodies in the diagnosis and follow-up of Wegener's granulomatosis. Mayo Clin Proc. 1989 Jan;64(1):28-36.

31. Tervaert JW, van der Woude FJ, Fauci AS, Ambrus JL, Velosa J, Keane WF et al: Association between active Wegener's granulomatosis and anticytoplasmic antibodies. Arch Intern Med. 1989 Nov;149(11):2461-5.

32. Terrier B, Saadoun D, Sène D, Ghillani P, Amoura Z, Deray G et al: Antimyeloperoxidase antibodies are a useful marker of disease activity in antineutrophil cytoplasmic antibody-associated vasculitides. Ann Rheum Dis. 2009 0ct;68(10):1564-71.

33. Jennette JC, Nachman PH: ANCA Glomerulonephritis and Vasculitis. Clin J Am Soc Nephrol 12: 1680-1691, 2017.

\section{Figures}




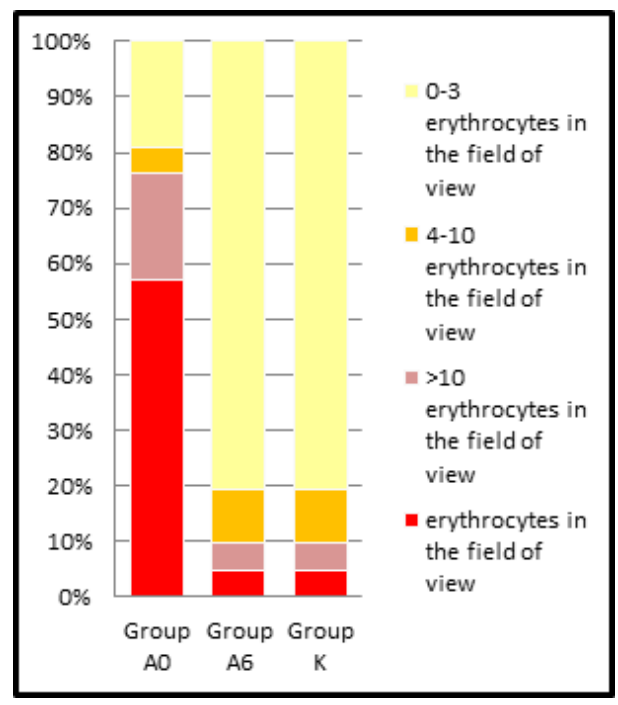

Figure 1

Severity of erythrocyturia in the sediment of a single urine sample. 